\title{
Earth-bound rules threaten quest for extraterrestrial life
}

Boston. Astronomers at the Ohio State University who have been engaged in the world's longest running search for extraterrestrial intelligence (SETI) are trying to save their radiotelescope - one of only a handful of such facilities dedicated to SETI activities - from eviction.

The threat to the university's so-called 'Big Ear' telescope comes on top the loss of its grant support from the National Aeronautics and Space Administration (NASA), whose budget for SETI was eliminated by Congress last year.

Since then, existing SETI projects have scrambled to find alternative funding sources. For the Ohio State radio survey, which began in 1972, this has been a double blow, as the 10-year lease for the Big Ear telescope - one of the largest radiotelescopes in the world - expires on 30 July. The owner of the property wants the tele-

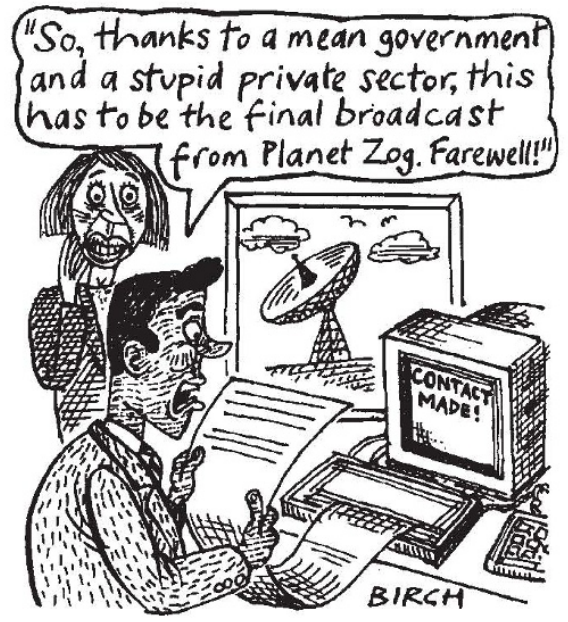

scope to be torn down to make room for the expansion of a golf course and the construction of new homes.

"The timing is bad, with our lease coming up for renewal shortly after the cut-off in federal funds," explains Robert Dixon, who directs the Ohio State SETI programme. "When the university asks us what [outside] grants we have, we're forced to say none."

In principle - and assuming that the university continues to pay for rent, electricity and bare upkeep - the all-volunteer project would still be able to keep.going without any outside funding, as it has often done in the past. But there remains a further obstacle.

A provision in the lease stipulates that the telescope must be painted. Federal lead paint laws will make this a difficult and costly job running into $\$ 100,000$ or more - an expense the university may not be willing to defray. "It's a ridiculous situation," Dixon observes. "Environmental laws, which were designed to keep small children from eating paint chips in their homes, may end up killing our telescope. It's a unique dilemma in the history of astronomy."

The Planetary Society has asked its members, and others concerned about the fate of Big Ear, to express their support by writing to the president of the university, E. Gordon Gee. Many have done so, including Carl Sagan, Arthur C. Clarke, and Paul Horowitz, a Harvard physicist.

"The Ohio State University team has been a pioneer in SETI, responsible for many innovations in radiotelescope design," says Horowitz, who heads his own Megachannel Extraterrestrial Assay (META) SETI project at Harvard. "It would be a pity for such a venerable and high-quality group to have to close its doors."

Unlike its Ohio State counterpart, the future of META is relatively secure, thanks to donations from the Planetary Society, the Bosack/Kruger Foundation and other sources. "Private funding is much more stable [than federal funding] when you can get it, because it is not subject to the whims and vagaries of Congress," Horowitz says.

His own programme has recently benefited from another windfall. Micron Technology Inc., the largest manufacturer of computer memory chips in the United States, has agreed to donate 3,420 megabytes of memory chips - worth over $\$ 100,000$ - if Planetary Society members can match this contribution.

Once the memory chips are installed later this year, META will become BETA - for Billion Channel Extraterrestrial Assay - as its receiver will be able to analyse a quarter of a billion radio channels simultaneously.

The upgrade will lead to a thousandfold improvement in search capability, and BETA will then be able to scan more channels over a wider range of frequencies than any other SETI effort. Nevertheless, Horowitz believes that with the enormity of the challenge - sifting for evidence of an advanced civilization among 400 billion stars in the Milky Way - it is important to keep several programmes alive, especially those using different search strategies.

"SETI is seriously underfunded worldwide, given that the detection of just one signal of extraterrestrial, and artificial, origin would be the greatest discovery in the history of the human race," he says.

Robert Dixon agrees. "This is one of the most important questions that humans have sought to answer, and we've barely scratched the surface." Dixon acknowledges, however, that the task will require patience and perseverance. "We've known from the beginning that this would be a difficult problem to solve."
Steve Nadis

\section{IMAGE \\ UNAVAILABLE FOR COPYRIGHT REASONS}

Mystical madonna: will science reveal the origins of mystery blood?

\section{DNA evidence called to check 'holy tears'}

London. The city of Rome is expecting later this month to host another meeting between the diverse worlds of science and religious belief, this time on slightly different terms than celebrated encounters of the past.

Rather than being castigated as heretics, the researchers in question - forensic scientists from the US Federal Bureau of Investigation (FBI) - have, at least according to the Italian authorities, been invited to use DNA analysis and other contemporary techniques to authenticate the bizarre case of a figurine of the Virgin Mary, said to be weeping "tears of blood".

Last week, Cardinal Girolamo Grillo, Bishop of the port of Civitavecchia, northwest of Rome appeared on Italian television claiming to have witnessed a mass-produced statue of the Madonna shedding tears of red liquid after morning mass. "It must be a miracle. They are surely the tears of Jesus," the Cardinal proclaimed.

But one particular viewer was not convinced. Suspecting the work of a charlatan, a city magistrate, Antonio Albano, impounded and locked up the figurine, which had been bought by an electrical worker during a visit to the famous shrine of Medjugorje in the former Yugoslavia.

Doctors at Rome's Gemelli Polyclinic hospital - where the Pope receives treatment - have confirmed that the liquid is male blood. Albano says he has now asked the FBI to carry out DNA tests comparing the tears with the blood of the statue's owner, Fabio Gregori, and his entire family.

The Vatican has so far maintained a diplomatic silence on the affair. But Grillo is said to be furious at the implication that science is being used to measure the integrity of a man of God. "The blood is masculine, so it has to be the tears of Jesus," Grillo told an Italian newspaper. "They have impounded the Holy Madonna and her Bishop is being treated like a criminal suspect." The FBI, meanwhile, says that no invitation to carry out a 'scientific' analysis of the tears has been officially received. 